Research Article

\title{
Effect of Ferronickel Slag Powder on Strength of Soil in Marine Environment
}

\author{
Feng Chen $\mathbb{D}^{1,2}$ and Shenghao Tong $\mathbb{D}^{2}$ \\ ${ }^{1}$ College of Engineering, Fujian Jiangxia University, Fuzhou 350108, China \\ ${ }^{2}$ College of Environment and Resources, Fuzhou University, Fuzhou 350108, China
}

Correspondence should be addressed to Shenghao Tong; 994553321@qq.com

Received 27 August 2020; Revised 23 November 2020; Accepted 30 November 2020; Published 9 December 2020

Academic Editor: Shangtong Yang

Copyright (C) 2020 Feng Chen and Shenghao Tong. This is an open access article distributed under the Creative Commons Attribution License, which permits unrestricted use, distribution, and reproduction in any medium, provided the original work is properly cited.

\begin{abstract}
Over the past few years, soil-cement has been widely used in marine geotechnical engineering; meanwhile, the safety of soilcement in marine environment has attracted wide attention. In order to study the influence of composite ferronickel slag powder on the strength and micro morphology of soil-cement in marine environment, the composite nickel iron slag powder was added into the soil-cement in this paper. The unconfined compressive strength test, erosion resistance coefficient analysis, SEM, and EDS test analysis of soil-cement were carried out.. Results showed that the marine environment had great influences on the strength of soil-cement, and the addition of compound nickel-iron slag powder can enhance the strength of soil-cement, and the deterioration of the strength of soil-cement is reduced. In addition, the compound ferronickel slag powder has microaggregate effect, morphological effect, and activation effect, which not only improves compaction rate of soil-cement and prevents invasion of erosive ions in marine environment but also has positive effects on the performance of soil-cement.
\end{abstract}

\section{Introduction}

The soil-cement is a kind of compound material which is mainly mixed by soil, cement, water, and additive upon certain proportion [1]. Such soil-cement has been widely used in engineering due to unique features $[2,3]$, such as flexibility, commercial availability, and low permeability, and achieved remarkable results. For example, O'Rourke and O'Donnell [4] introduced performance of tieback evacuation by the deep mixing method and consolidation by injection grouting for soil mixing wall of underlying marine clay in Boston. Wang and Zheng [5, 6] took several different layout plans for soil-cement mixing piles in tunnel excavation for reinforcing the soil mass and discussed protection of different soil-cement reinforced areas on adjacent tunnels. Daraei et al. [7] used the soil-cement mixing method to reinforce road slope and studied stability of reinforced road slope. Al-Bared et al. [8-10] studied the engineering characteristics of marine clay reinforced by recycled ceramic tiles and discussed the beneficial effects of recycled ceramic tiles and tires in partially replacing cement, sand, or stone in concrete.

Over the past few years, as engineering construction technology rapidly develops, sustainable development strategy for modern ocean development has attracted more and more attentions. Meanwhile, soil-cement has played an irreplaceable role in marine geotechnical engineering such as coastal engineering, engineering on a sea island, and subsea tunnel. There are a large number of erosive ions in marine environment that have corrosive effects on soilcement [11]; therefore, safe application and durability of soil-cement in engineering have attracted more and more attention from scholars. Pham et al. [12] studied the deterioration effect of sulfate in marine environment on soilcement piles. Jiang et al. [13] studied influences of the additive amount of soil-cement and cement type on the mechanical property of soil-cement reinforced silt soil in China's southeast coastal region. Shihata and Baghdadi [14] studied the influences of erosive ions on durability and compressive strength of soil-cement when soil-cement was 
exposed to underground water containing saline ions for a long term. Li et al. [15] studied mechanical properties and failure mechanism of red clay reinforcement with cement in a chemical erosion environment.

The addition of specific additives in soil-cement has not only improved mechanical properties and durability of soilcement but also achieved good economic benefits. At present, common additives for soil-cement mainly include sodium hydroxide, sulfate, calcium chloride, fiber, fly ash, mineral powder, and nano silicon powder. Tran et al. [16, 17] mixed a certain amount of corn silk fiber in soil-cement and studied the mechanical properties and stability of soil-cement. The study results achieved by Chen [18] indicated that the addition of a proper amount of basalt fiber in soil-cement improved mechanical properties of soil-cement. Meng et al. [19] studied influences of compound nano calcium carbonate on strength and microstructure of soil-cement in marine environment and indicated that marine environment had large influences on strength and durability of soilcement. Kalantari et al. [20] indicated that silicon powder had improved the strength and bearing capacity of soilcement. Kolias et al. [21] and Karpisz and Jaworski [22] studied the influences of fly ash on the strength and stability of soil-cement.

Ferronickel slag is the industrial solid waste residue produced when nickel alloy is smelted, which will result in serious environmental pollution when not being handled properly. Nowadays, some scholars have used ferronickel slag for studying the production of cement [23], concrete [24], and synthetic materials [25], but there are few studies on applying it to soil-cement. Ferronickel slag powder is featured with potential activation [26], low price, and durability [27]. This paper has, through mixing compound admixture made by ferronickel slag powder and mineral powder into soil-cement, compared and analyzed performance difference of soil-cement in freshwater and marine environment; besides, analyzed microstructure of soil-cement by SEM-EDS test and studied solidification mechanism of above admixture on soil-cement. Grinding ferronickel slag into powder and applying it to soil-cement material has not only effectively solved the problem of waste ferronickel slag but also reduced the construction cost of engineering.

\section{Materials and Methods}

2.1. Materials. The main test materials used in this study include soil, cement, water, and compound ferronickel slag powder. In this study, the earth material was sampled from the silt in the foundation pit of a subway station in Fuzhou City (Fujian Province, China) with a $\mathrm{pH}$ value of 6.82. The basic physical and mechanical indexes of soil are shown in Table 1. For this study, we have selected common Portland cement (PO 42.5), the quality of which satisfies with that of GB175-2007 common Portland cement. Besides, we have used pure water which is purified from tap water. Compound ferronickel slag powder is consisted of ferronickel slag powder and granulated blast furnace slag powder. Although ferronickel slag powder is cost-effective, its chemical activation is low. In order to conquer this disadvantage, granulated blast furnace slag powder with high chemical activation has been mixed in ferronickel slag powder as per their mass ratio 2:1 (ferronickel slag powder/granulated blast furnace slag powder). The chemical composition of cementitious materials is shown in Tables 2 and 3. Figure 1 shows a sample of compound ferronickel slag powder and SEM image. We can see from SEM that compound ferronickel slag powder is an irregular fragment with clear edge and corner, smooth particle surface, and different particle sizes.

2.2. Strength Test. The unconfined compressive strength test has been conducted here in accordance with JGJT 233-2011 Specification for mix proportion design of soil-cement to study the strength property of soil-cement. The standard cubic sample with a size of $70.7 \mathrm{~mm} \times 70.7 \mathrm{~mm} \times 70.7 \mathrm{~mm}$ has been used for the test with MTS landmark 370.25.

In this paper, the water-cement ratio of soil-cement is 0.5 , and the mixing ratio of cementitious material is $15 \%$. The cement in soil-cement is replaced by compound ferronickel slag powder. The compound ferronickel slag powder that has equivalent mass with cement is mixed into soil-cement, for which mixing ratio is $0 \%, 10 \%, 20 \%, 30 \%$, $40 \%$, and $50 \%$. Two curing environments have been set in this study, namely, freshwater and marine environment, with curing periods $7 \mathrm{~d}, 28 \mathrm{~d}, 60 \mathrm{~d}$, and $90 \mathrm{~d}$, respectively. The marine environment is manually prepared in accordance with Salt Manufacturing Industry Manual. The main saline content in seawater is shown in Table 4 . Each test is provided with 5 samples, and 240 soil-cement samples have been prepared in total. Forming and curing of soil-cement samples were performed according to the Chinese Standard JGJT 233-2011 Specification for Mix Proportion Design of Soil-Cement. The compression test of soil-cement is shown in Table 5.

The unconfined compressive strength of soil-cement is calculated as below:

$$
f_{u}=\frac{p}{A}
$$

where $P$ refers to the failure load of the sample $(N)$; $A$ refers to the compression area between the sample and clamp $\left(\mathrm{mm}^{2}\right) ; f_{u}$ refers to the unconfined compressive strength $(\mathrm{MPa})$, rounded to $0.01 \mathrm{MPa}$.

2.3. Antierosion Analysis. The saline ions in seawater have erosion effects on soil-cement [7]. Therefore, this paper has, in accordance with evaluation index of anti-erosion property of cement described in GB/T 749-2008 test method for determining the capacity of resisting sulfate corrode of cement, designed an evaluation method appropriate to evaluate antierosion property of soil-cement in marine environment; besides, by comparing and analyzing strength difference of soil-cement in freshwater and marine environment, the property of resisting environmental erosion of 
TABLE 1: Basic physical and mechanical indexes of soil.

\begin{tabular}{lccccc}
\hline Soil sample & Moisture content $w(\%)$ & Unit weight $r\left(\mathrm{kN} / \mathrm{m}^{3}\right)$ & Void ratio $e$ & Plasticity index $I p$ & Liquidity index $I_{L}$ \\
\hline Silt & 58.5 & 16.01 & 1.53 & 19.8 & 1.47
\end{tabular}

TABLE 2: Chemical composition of compound admixture.

\begin{tabular}{lccccccccc}
\hline Composition & $\mathrm{SiO}_{2}$ & $\mathrm{Al}_{2} \mathrm{O}_{3}$ & $\mathrm{CaO}$ & $\mathrm{MgO}$ & $\mathrm{TiO}_{2}$ & $\mathrm{MnO}$ & $\mathrm{Fe}_{2} \mathrm{O}_{3}$ & $\mathrm{SO}_{3}$ & $\mathrm{LOI}$ \\
\hline Ferronickel slag powder (\%) & 35.82 & 21.46 & 29.22 & 9.46 & 0.78 & 0.57 & 1.33 & 0.16 & 2.43 \\
Granulated blast furnace slag powder (\%) & 32.00 & 16.81 & 36.12 & 10.59 & 0.93 & 0.9 & 2.29 & 0.14 & 0.16 \\
\hline
\end{tabular}

TABle 3: Chemical composition of common Portland cement (PO 42.5).

\begin{tabular}{lccccccccc}
\hline Composition & $\mathrm{CaO}$ & $\mathrm{SiO}_{2}$ & $\mathrm{Al}_{2} \mathrm{O}_{3}$ & $\mathrm{Fe}_{2} \mathrm{O}_{3}$ & $\mathrm{SO}_{3}$ & $\mathrm{MgO}$ & $\mathrm{f}-\mathrm{CaO}$ & $\mathrm{Others}$ & $\mathrm{LOI}$ \\
\hline Portland cement (\%) & 62.55 & 21.69 & 4.38 & 3.34 & 2.89 & 2.05 & 0.57 & 0.84 & 1.59 \\
\hline
\end{tabular}

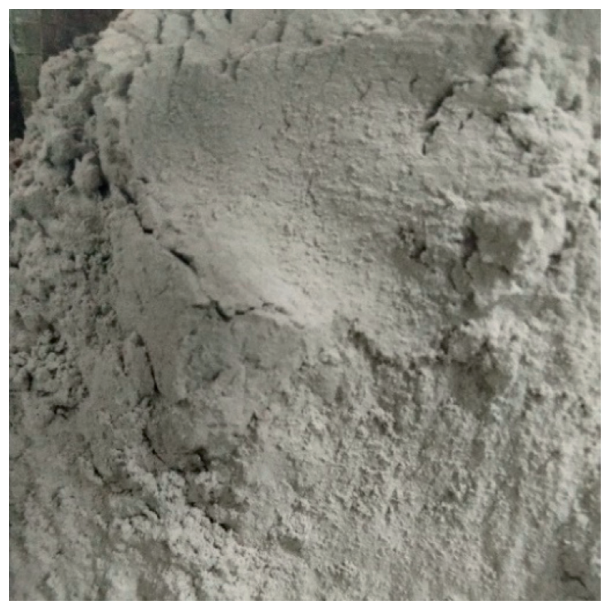

(a)

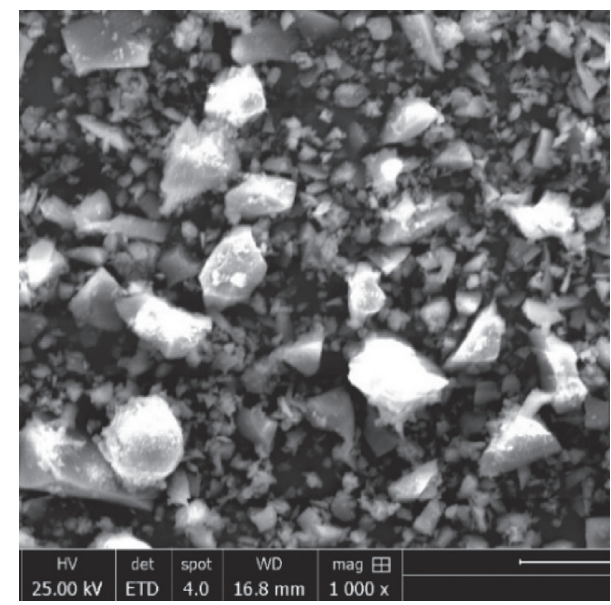

(b)

Figure 1: Compound ferronickel slag powder. (a) Appearance of compound. (b) SEM image of compound.

TABLE 4: The main salt content of seawater.

\begin{tabular}{lcccccccc}
\hline Salt of seawater & $\mathrm{NaCl}$ & $\mathrm{MgCl}_{2}$ & $\mathrm{MgSO}_{4}$ & $\mathrm{CaSO}_{4}$ & $\mathrm{~K}_{2} \mathrm{SO}_{4}$ & $\mathrm{CaCO}_{3}$ & $\mathrm{MgBr}_{2}$ & $\mathrm{Total}$ \\
\hline Content (\%) & 27.21 & 3.81 & 1.66 & 1.26 & 0.86 & 0.12 & 0.08 & 35 \\
\hline
\end{tabular}

TABLe 5: Unconfined compressive strength test.

\begin{tabular}{|c|c|c|c|c|c|c|c|c|}
\hline \multirow{2}{*}{ No. } & \multirow{2}{*}{ Cement $(\%)$} & \multirow{2}{*}{ Water cement ratio } & \multirow{2}{*}{ Compound admixture addition (\%) } & \multirow{2}{*}{ Environment } & \multicolumn{4}{|c|}{ Quantity of samples (piece) } \\
\hline & & & & & $7 \mathrm{~d}$ & $28 \mathrm{~d}$ & $60 \mathrm{~d}$ & $90 \mathrm{~d}$ \\
\hline A-0 & \multirow{12}{*}{15} & \multirow{12}{*}{0.5} & 0 & \multirow{6}{*}{ Freshwater } & 5 & 5 & 5 & 5 \\
\hline A-1 & & & 10 & & 5 & 5 & 5 & 5 \\
\hline A-2 & & & 20 & & 5 & 5 & 5 & 5 \\
\hline A-3 & & & 30 & & 5 & 5 & 5 & 5 \\
\hline A-4 & & & 40 & & 5 & 5 & 5 & 5 \\
\hline A-5 & & & 50 & & 5 & 5 & 5 & 5 \\
\hline B-0 & & & 0 & \multirow{6}{*}{ Seawater } & 5 & 5 & 5 & 5 \\
\hline B-1 & & & 10 & & 5 & 5 & 5 & 5 \\
\hline B-2 & & & 20 & & 5 & 5 & 5 & 5 \\
\hline B-3 & & & 30 & & 5 & 5 & 5 & 5 \\
\hline B-4 & & & 40 & & 5 & 5 & 5 & 5 \\
\hline B-5 & & & 50 & & 5 & 5 & 5 & 5 \\
\hline
\end{tabular}


the soil-cement was studied and antierosion coefficient $K_{T}$ was calculated, as shown in the following equation:

$$
K_{T}=\frac{f_{a}}{f_{b}}
$$

where $K_{T}$ refers to the antierosion coefficient of soil-cement, rounded to $0.001 ; f_{a}$ refers to the compressive strength of soil-cement at $T$ in freshwater environment; $f_{b}$ refers to the compressive strength of soil-cement at $T$ in the mariner environment; and $T$ refers to soak time in water.

2.4. SEM-EDS Analysis. QUANTA250 multifunction scanning electron microscope for tungsten filament has been used for SEM test which has compared and analyzed microstructure of soil-cement with the addition of ferronickel slag powder and mineral powder in freshwater and marine environment. Besides, QUANTAX200 X-gamma energy dispersive spectroscope has been used for EDS test which has compared and analyzed the difference of soil-cement in element mass ratio in the above two environments. Because of multiple additions, this study has, based on results of the strength test, selected representative mix proportion for microanalysis.

\section{Results}

3.1. Effect of Compound Ferronickel Slag Powder on Strength. The comparison of different cement contents as studied in $[28,29]$ showed that $15 \%$ of cement was the optimum value at which the strength was maximum at 90 days curing period. Figure 2, respectively, show results of the strength test for soil-cement in freshwater and marine environment. For soil-cement with the addition of ferronickel slag powder, the growth rate of a fixed base for strength increases as its additive amount increases in freshwater and marine environment. At 7 days, soil-cement has low strength and its strength curve grows slowly as the additive amount of ferronickel slag powder increases. At 28 days, the overall growth for strength of soil-cement rises rapidly. The strength growth of soil-cement with the additive amount of ferronickel slag powder in range between $20 \%$ and $40 \%$ is larger than the one with additive amount of ferronickel slag powder in range between $0 \%$ and $20 \%$; however, the strength of soil-cement with additive amount of ferronickel slag powder in range between $40 \%$ and $50 \%$ increases slowly. Compared to early 60 days and 90 days, the growth trend in curve of relationship between the strength of soil-cement and additive amount of ferronickel slag powder rises dramatically, which is particularly obvious in the range between $20 \%$ and $40 \%$ for additive amount of ferronickel slag powder. The reason for the increase in the strength of soilcement was due to the pozzolanic effect of cement and composite nickel-iron slag powder. Furthermore, the admixtures addition improved soil-cement workability, as explained by Lemonis et al. [30]; the ferronickel slag could be readily utilized as substitutes for cement. Therefore, the addition of ferronickel slag powder has improved the strength property of soil-cement which rises as the additive amount of ferronickel slag powder increases.

In order to intuitively compare and analyze similarities and differences in strength of soil-cement in different environments, a curve for strength of soil-cement in freshwater and marine environment has been plotted, as shown in Figure 3. Besides, in order to better analyze reinforcement effect of the additive amount of ferronickel slag powder on strength of soil-cement and its development degree, this study has compared and analyzed strength of soil-cement with addition of ferronickel slag powder at each period by chain relative ratio and calculated the growth rate of chain relative ratio as shown in Table 6.

(1) At 7 days, growth trends of two strength curves for freshwater and marine environment are basically consistent. At early hydration age, strength of cement-soil increases quickly [13], and the environment has little influence on the strength of soilcement [31]. However, the strength curve of soilcement in marine environment is slightly lower than the one in freshwater, indicating adverse influence of marine environment on strength of soil-cement with addition of ferronickel slag at 7 days. For 5 groups of soil-cement with the additive amount of ferronickel slag powder between $0 \%$ and $50 \%$ in freshwater, the chain growth rate is $1.9 \%, 9.3 \%, 5.1 \%, 37.6 \%$, and $-1.0 \%$, respectively. For 5 groups of soil-cement with the additive amount of ferronickel slag powder between $0 \%$ and $50 \%$ in marine environment, the chain growth rate is $20.7 \%, 7.4 \%, 11.9 \%, 34.2 \%$, and $1.0 \%$, respectively. As a result, the addition of compound ferronickel slag powder is useful for reinforcing the strength of soil-cement.

(2) At 28 days, under same additive amount of compound ferronickel slag powder, the strength of soilcement in marine environment decreases obviously compared to the one in freshwater, and decreased level of strength under low additive amount is slightly larger than the one under high additive amount. This indicates that ferronickel slag powder has played a high role in reinforcing the strength of soil-cement at 28 days. However, adverse effects of marine environment also increase at this period, resulting in an obvious decrease of strength of soilcement in marine environment compared to the one in freshwater. The chain growth rate is $6.3 \%, 11.1 \%$, $19.8 \%, 20.4 \%$, and $14.2 \%$, respectively, for 5 groups of soil-cement in freshwater, and $6.4 \%, 12.4 \%, 21.1 \%$, $22.5 \%$, and $11.3 \%$, respectively, for 5 groups of soilcement in the marine environment. All chain growth rates are positive and tend to rise, and then, decrease as the additive amount of admixture increases. Besides, the chain growth speed for strength is the fastest when the additive amount of ferronickel slag powder reaches $40 \%$. Therefore, the optimal additive amount of compound ferronickel slag powder is $40 \%$ to realize beneficial reinforcement effect for the strength of soil-cement. 


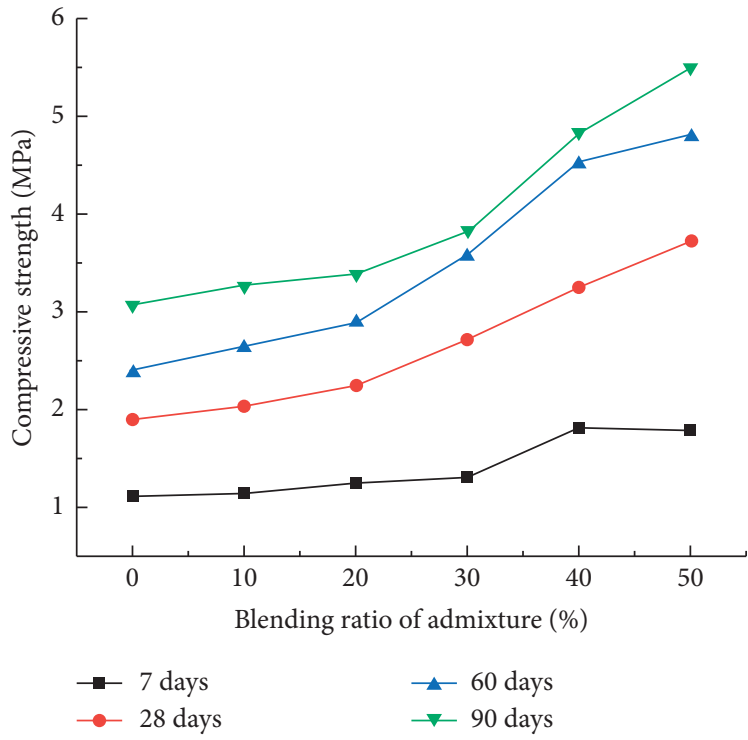

(a)



(b)

Figure 2: Strength of soil-cement in (a) freshwater environment and (b) marine environment.

(3) Similarly, at 60 days and 90 days, the strength of soilcement rises dramatically as the additive amount of ferronickel slag powder increases. The hydration effect of cement in soil-cement tends to be stable, while chemical activation of ferronickel slag powder plays an important role in strength development. The strength development curves of soil-cement in freshwater and marine environment have shown obvious difference; that is, the difference in the strength of soil-cement in above two environments is large when additive amount of compound ferronickel slag powder is low. We can see from Table 6 that the growth rate of strength increases and then decreases as additive amount increases; therefore, the strength of soil-cement is better reinforced when additive amount of the admixture is $40 \%$. The reason for the increase in the strength of soil-cement was due to the pozzolanic effect of cement and composite nickel-iron slag powder. The setting time of composite nickel-iron slag powder is longer than that of cement, and the microaggregate effect can be exerted to fill the pores [30]. The increase of cement soil strength is greater than the deterioration of cement soil strength caused by marine environment [32].

3.2. Antierosion Coefficient of Soil-Cement. The saline ions in marine environment have corrosive effects on soil-cement. According to strength test for soil-cement, marine environment has adverse effects on strength of soil-cement. Figure 4 shows antierosion coefficient calculated upon equation (2) at 7 days. Although the curve of coefficient $K_{7}$ tends to rise as a whole, $K_{7}$ has local irregular changes as additive amount of admixture changes; as a result, antierosion coefficient $K_{7}$ cannot better reflect the capacity of resisting erosion of marine environment for soil-cement. Therefore, this study has not used it as an evaluation index; because the hydration effect of cement in soil-cement is strong at 7 days, corrosive ions in marine environment have lower erosion and deterioration effect on strength of soilcement compared to its solidification; at this time, strength of soil-cement grows rapidly, but cannot develop steadily.

According to development rules, the strength of soilcement can continuously increase after 28 days, and the marine environment has obvious influences on strength of soil-cement. Therefore, this study has used antierosion coefficients $K_{28}, K_{60}$, and $K_{90}$ after 28 days as evaluation indexes. Besides, according to equation (2), this paper considers that the capacity of resisting erosion of marine environment is stronger when antierosion coefficient of soilcement is closer to 1 under the same period. Figure 5 shows antierosion coefficients at 28 days, 60 days, and 90 days. We can see from Figure 5 that antierosion coefficient of soilcement $K_{T}$ at 28 days is larger than 0.9 and shows a small difference. Besides, antierosion coefficient tends to decrease as the erosion period increases, and decreasing speed of antierosion coefficient for soil-cement without admixture is the fastest. As a result, compared to soil-cement with the addition of ferronickel slag powder, the one without ferronickel slag powder shows a worse capacity of resisting erosion of marine environment. The antierosion coefficient $K_{T}$ decreases faster when the additive amount of ferronickel slag powder is low. Therefore, when the additive amount of ferronickel slag powder is less than $20 \%, K_{T}$ decreases faster than the one when the additive amount is larger than $20 \%$. However, antierosion coefficient decreases slightly when the additive amount of ferronickel slag powder is larger than $50 \%$. Meanwhile, we can see that $K_{28}, K_{60}$, and $K_{90}$ rise and then decrease as the additive amount of ferronickel slag powder changes. This indicates that the capacity of resisting 




(a)

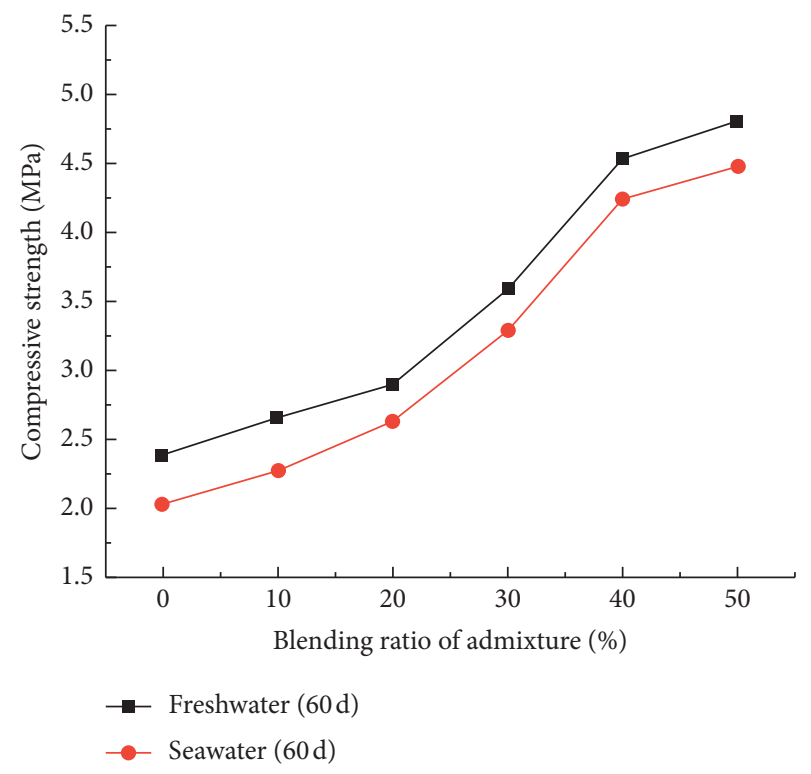

(c)

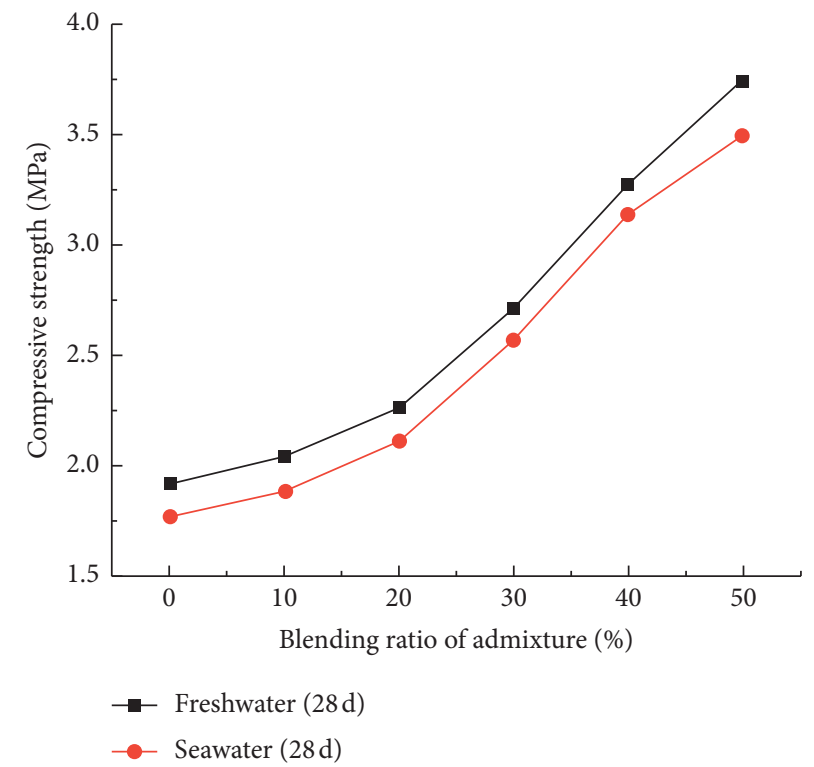

(b)



(d)

Figure 3: Strength curve of soil-cement in freshwater and marine environment. (a) 7 days. (b) 28 days. (c) 60 days. (d) 90 days.

TABLE 6: Strength growth rate of cement soil.

\begin{tabular}{lcccc}
\hline \multirow{2}{*}{ Growth rate } & \multicolumn{4}{c}{ Age } \\
& $7 \mathrm{~d}$ & $28 \mathrm{~d}$ & $60 \mathrm{~d}$ & $90 \mathrm{~d}$ \\
\hline A-1 to A-0 & $1.9 \%$ & $6.3 \%$ & $11.0 \%$ & $6.0 \%$ \\
A-2 to A-1 & $9.3 \%$ & $11.1 \%$ & $9.2 \%$ & $3.8 \%$ \\
A-3 to A-2 & $5.1 \%$ & $19.8 \%$ & $23.7 \%$ & $12.8 \%$ \\
A-4 to A-3 & $37.6 \%$ & $20.4 \%$ & $26.5 \%$ & $25.9 \%$ \\
A-5 to A-4 & $-1.0 \%$ & $14.2 \%$ & $6.0 \%$ & $13.8 \%$ \\
B-1 to B-0 & $20.7 \%$ & $6.4 \%$ & $12.8 \%$ & $7.3 \%$ \\
B-2 to B-1 & $7.4 \%$ & $12.4 \%$ & $15.5 \%$ & $9.1 \%$ \\
B-3 to B-2 & $11.9 \%$ & $21.1 \%$ & $25.1 \%$ & $13.2 \%$ \\
B-4 to B-3 & $34.2 \%$ & $22.5 \%$ & $29.1 \%$ & $27.8 \%$ \\
B-5 to B-4 & $1.0 \%$ & $11.3 \%$ & $5.3 \%$ & $12.7 \%$ \\
\hline
\end{tabular}

Note: growth rate is the chain growth rate. the erosion of marine environment for soil-cement is improved as additive amount of ferronickel slag powder increases, but such a trend will not increase infinitely. The capacity of resisting erosion of the marine environment will decrease slightly when the additive amount of ferronickel slag powder exceeds $40 \%$. Therefore, the optimal additive amount of above admixture for soil-cement resisting erosion is $40 \%$.

3.3. SEM-EDS Analysis. The irregular fiber shape or flocculated C-S-H gel, hexagonal plate shape $\mathrm{Ca}(\mathrm{OH})_{2}$ crystal, and a small amount of fine needle-shaped ettringite are produced by hydration [33]. Figures 6(a) and 6(b) show SEM 


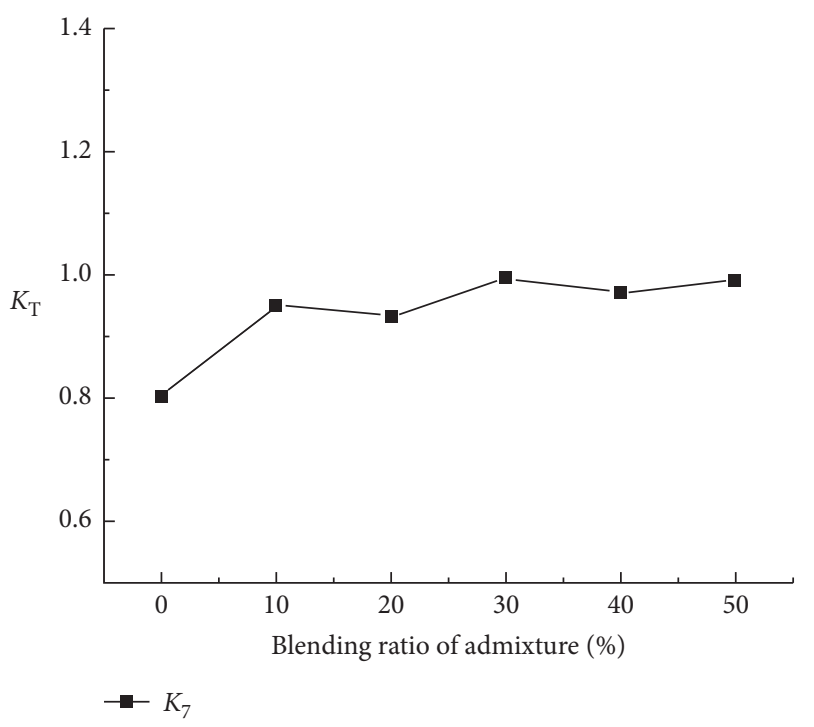

Figure 4: Change of coefficient $K_{7}$.
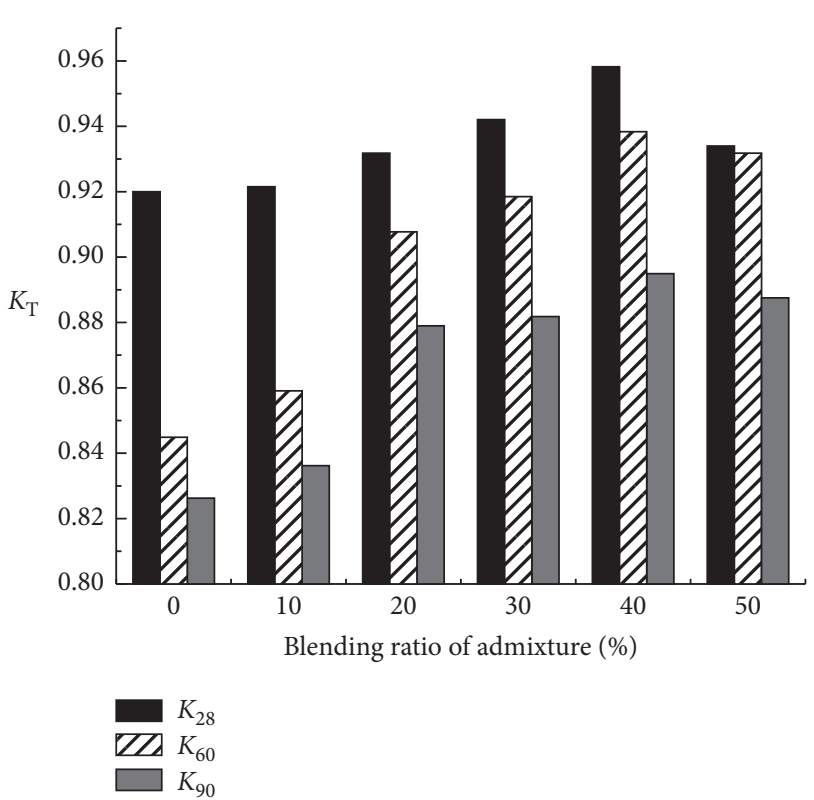

Figure 5: Change of coefficient $K_{T}$.

microstructural images of soil-cement in freshwater environment at 60 days. The soil-cement contains a lot of flocculent C-S-H gels and few needle-shaped ettringite (AFt). We cannot find gravel-shaped ferronickel slag powder with clear edges in the microstructural image and distinguish soil particle and ferronickel slag powder easily. The gel produced from binding material in soil-cement can wrap and cover soil particle and ferronickel slag powder and even embed CH tabular crystal and needle-shaped AFt in it. There are many cellular voids in soil-cement; compared to common soil-cement, soil-cement with the addition of compound ferronickel slag powder has a denser microstructure. This is due to the microaggregate effect of composite nickeliron slag powder filling the internal pores of cement soil [34].
The glass body in the composite nickel-iron slag powder can play a pozzolanic effect, and the hydration products can make the cement-soil more dense.

Figures 6(c) and 6(d) show SEM microstructural images of soil-cement in marine environment at 60 days. The hydration products of soil-cement in marine environment also contain more flocculent C-S-H gels and few needle-shaped AFt. There are also more voids in soil-cement. However, internal hydration products in cement can fill in loose voids and combine soil particle with ferronickel slag powder to form a whole embedded space. Compared to freshwater environment, we can see more hexagonal plate type and laminated shape structure that can be recognized easily in soil-cement samples in marine environment. Based on elemental recognition of EDS, such a substance contains $\mathrm{CH}$ crystal and Friedel's salt crystal. The plate-type and laminated structure will increase as the additive amount of ferronickel slag powder increases, and the addition of ferronickel slag powder will slightly reinforce the binding capacity of $\mathrm{Cl}^{-}$in soil-cement; therefore, the content of Friedel's salt crystal in sheet structure is high. In addition, plasmas such as $\mathrm{SO}_{4}^{2-}$ and $\mathrm{Mg}^{2+}$ in marine environment will react with active mineral in soil-cement to produce a lot of expansible gels, AFt and $\mathrm{CH}-\mathrm{S}_{2}$, and other products [35]. When the amount of production reaches a certain value, it will not only decrease strength but also damage the integrity of soil-cement. However, microaggregate effect and activation effect of compound ferronickel slag powder will fill in voids of soil-cement to relieve invasion of corrosive materials.

Table 7 shows a mass ratio of main elements of C-S-H gel. There are more $\mathrm{O}$ and $\mathrm{Si}$ in soil-cement. The relative content of element $\mathrm{Ca}$ decreases as the additive amount of ferronickel slag powder increases. Moreover, $\mathrm{Ca} / \mathrm{Si}$ in soilcement decreases when the additive amount of compound ferronickel slag powder increases and slightly increases in marine environment. The lower the value of $\mathrm{Ca} / \mathrm{Si}$ is, the 


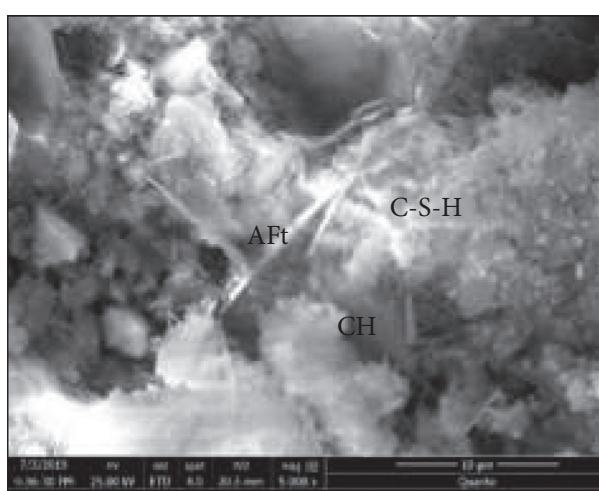

(a)

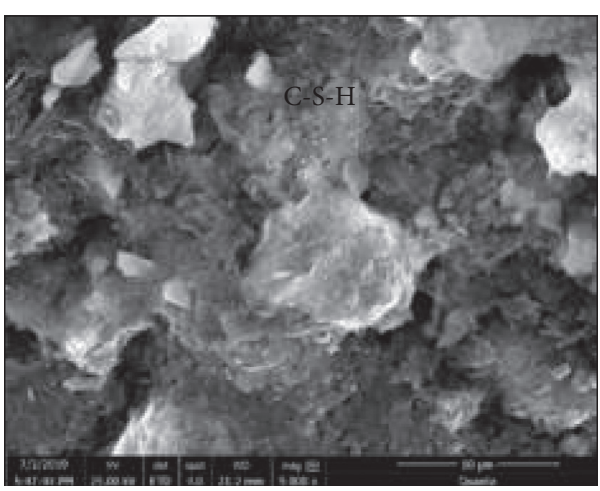

(c)

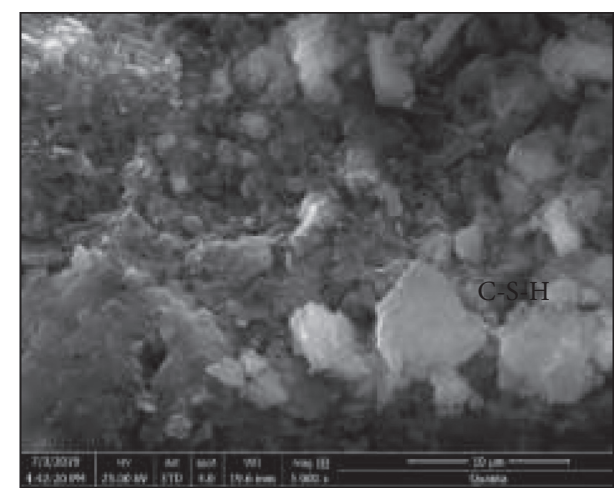

(b)

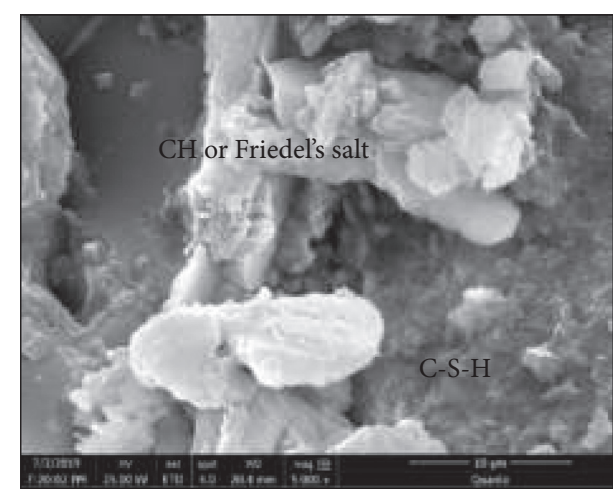

(d)

Figure 6: Microscopic morphology of soil-cement. (a) SEM image of A-0 t ( $\times 5000)$. (b) SEM image of A-4 ( $\times 5000)$. (c) SEM image of B-0 $(\times 5000)$. (d) SEM image of B-4 (×5000).

TABLE 7: Element mass ratio of C-S-H gel in EDS test.

\begin{tabular}{ccccccccccc}
\hline No. & $\mathrm{O}, w_{t}(\%)$ & $\mathrm{Si}, w_{t}(\%)$ & $\mathrm{Ca}, w_{t}(\%)$ & $\mathrm{Al}, w_{t}(\%)$ & $\mathrm{C}, w_{t}(\%)$ & $\mathrm{Fe}, w_{t}(\%)$ & $\mathrm{K}, w_{t}(\%)$ & $\mathrm{Mg}, w_{t}(\%)$ & $\mathrm{Cl}, w_{t}(\%)$ & $\mathrm{Ca} / \mathrm{Si}$ \\
\hline $\mathrm{A}-0$ & 49.23 & 20.81 & 11.25 & 6.99 & 7.53 & 2.45 & 1.35 & 0.39 & - \\
$\mathrm{A}-4$ & 44.38 & 21.47 & 7.82 & 9.78 & 9.05 & 2.32 & 4.45 & 0.73 & - \\
$\mathrm{B}-0$ & 50.82 & 15.83 & 11.7 & 8.56 & 6.81 & 2.09 & 1.82 & 1.68 & 0.54 \\
$\mathrm{~B}-4$ & 47.57 & 17 & 6.52 & 15.04 & 6.82 & 2.53 & 2.02 & 1.65 & 0.69 \\
\hline
\end{tabular}

better the polymerization degree of $\mathrm{C}-\mathrm{S}-\mathrm{H}$ gel produced from hydration will be, resulting in a denser structure; therefore, $\mathrm{Ca} / \mathrm{Si}$ can reflect the compaction rate of soil-cement to a certain degree. In addition, the soil-cement is denser after mixing with compound ferronickel slag powder. However, marine environment is one of the factors having adverse effects on soil-cement. Besides, a large number of element $\mathrm{Cl}$ can be detected from soil-cement suffering from erosion of marine environment because $\mathrm{Cl}^{-}$can react with $\mathrm{C}_{3} \mathrm{~A}$ in cement and $\mathrm{CH}$ dissolved after hydration reaction to generate Friedel's salt crystal. The content of element $\mathrm{Cl}$ increases slightly as the content of ferronickel slag powder increases, which indicates that the addition of compound ferronickel slag powder slightly reinforces the combining capacity of its $\mathrm{Cl}^{-}[36]$.

\section{Conclusions}

We can draw conclusions from this study as follows:
(1) The addition of a certain amount of compound ferronickel slag powder is useful for enhancing strength property of soil-cement, and the strength tends to rise as the additive amount of the above admixture increases. When the additive amount of compound ferronickel slag powder reaches $40 \%$, the growth rate of such strength starts to decrease.

(2) Marine environment has adverse effects on strength of soil-cement. However, the addition of compound ferronickel slag powder relieves the deterioration effect of marine environment on the strength of soilcement. Besides, the optimal additive amount of the above admixture for soil-cement in marine environment is $40 \%$. This is due to the corrosion resistance of the compound ferronickel slag powder, the pozzolanic effect, and the microaggregate effect.

(3) The antierosion coefficient of soil-cement with the addition of compound ferronickel slag powder has a time effect, and antierosion coefficient KT after 28 
days can better determine the antierosion capacity of soil-cement. When the antierosion coefficient of soilcement is closer to 1 , the antierosion property of soilcement is better. In this study, antierosion property is better when the additive amount of admixture is $40 \%$.

(4) According to microstructural analysis for compound ferronickel slag powder based on SEM and EDS, hydration product in soil-cement can effectively combine soil particles with compound ferronickel slag powder, forming a dense structure. The higher the additive amount of compound ferronickel slag powder in soil-cement is, the smaller the $\mathrm{Ca} / \mathrm{Si}$ will be. Besides, because compound ferronickel slag powder has activation effect, microaggregate effect, and morphological effect, soil-cement with the addition of such admixture is denser. Meanwhile, marine environment has obvious influences on soilcement; as a result, soil-cement has a looser microstructure and even larger $\mathrm{Ca} / \mathrm{Si}$.

\section{Data Availability}

The strength test data used to support the findings of this study are included within the article.

\section{Conflicts of Interest}

The authors declare that they have no conflicts of interest regarding the publication of this paper.

\section{Acknowledgments}

This research was funded by the Natural Science Foundation of Fujian Province (Grant no. 2019J01883), National Natural Science Foundation of China Strait Joint Fund Project (Grant no. U1605242), and Innovation Team Support Program of Fujian Jiangxia University.

\section{References}

[1] X.-L. Duan and J.-S. Zhang, "Mechanical properties, failure mode, and microstructure of soil-cement modified with fly ash and polypropylene fiber," Advances in Materials Science and Engineering, vol. 2019, Article ID 9561794, 13 pages, 2019.

[2] D. A. Bruce, "An introduction to the deep soil mixing methods as used in geotechnical applications," European Journal of Organic Chemistry, vol. 578, no. 1, pp. 94-100, 2000.

[3] Q. Cheng, H. Xiao, Y. Liu, W. Wang, and L. Jia, "Primary yielding locus of cement-stabilized marine clay and its applications," Marine Georesources \& Geotechnology, vol. 37, no. 4, pp. 488-505, 2019.

[4] T. D. O’Rourke and C. J. O’Donnell, "Field behavior of excavation stabilized by deep soil mixing," Journal of Geotechnical and Geoenvironmental Engineering, vol. 123, no. 6, pp. 516-524, 1997.

[5] L. Wang and G. Zheng, "Protection of cement-soil reinforced regions for adjacent running tunnels during pit excavation," Chinese Journal of Rock Mechanics and Engineering, vol. 37, no. 1, pp. 3674-3685, 2018.
[6] L. Wang and G. Zheng, "Performance of piles at pit bottom during excavation of metro station," Electronic Journal of Geotechnical Engineering, vol. 21, no. 3, pp. 907-927, 2016.

[7] A. Daraei, B. M. A. Herki, A. F. H. Sherwani, and S. Zare, "Slope stability in swelling soils using cement grout: a case study," International Journal of Geosynthetics and Ground Engineering, vol. 4, no. 1, pp. 92-101, 2018.

[8] M. A. M. Al-Bared and A. Marto, "Evaluating the compaction behaviour of soft marine clay stabilized with two sizes of recycled crushed tiles," in Lecture Notes in Civil Engineering, B. Pradhan, Ed., vol. 9, Singapore, Springer, 2019.

[9] N. Zainuddin, N. Z. Mohd Yunus, M. A. M. Al-Bared, A. Marto, I. S. H. Harahap, and A. S. A. Rashid, "Measuring the engineering properties of marine clay treated with disposed granite waste," Measurement, vol. 131, pp. 50-60, 2019.

[10] M. A. M. Al-Bared, A. Marto, and N. Latifi, "Utilization of recycled tiles and tyres in stabilization of soils and production of construction materials-a state-of-the-art review," KSCE Journal of Civil Engineering, vol. 22, no. 10, pp. 3860-3874, 2018.

[11] G. Rajasekaran, "Sulphate attack and ettringite formation in the lime and cement stabilized marine clays," Ocean Engineering, vol. 32, no. 8-9, pp. 1133-1159, 2005.

[12] V. N. Pham, B. Turner, J. Huang, and R. Kelly, "Long-term strength of soil-cement columns in coastal areas," Soils and Foundations, vol. 57, no. 4, pp. 645-654, 2017.

[13] C. H. Jiang, F. Wu, T. Wang, and K. Fan, "The effect of cementation on the mechanical properties of muddy soil of East-south coastal area of China," Advanced Materials Research, vol. 740, pp. 636-639, 2013.

[14] S. A. Shihata and Z. A. Baghdadi, "Long-term strength and durability of soil cement," Journal of Materials in Civil Engineering, vol. 13, no. 3, pp. 161-165, 2001.

[15] X. Li, Y. Yang, H. Zhang, and Y. Yi, "Mechanical properties and failure mechanism of cemented red clay under chemical erosion environment," International Journal of Environment and Pollution, vol. 59, no. 2-4, pp. 156-168, 2016.

[16] K. Q. Tran, T. Satomi, and H. Takahashi, "Improvement of mechanical behavior of cemented soil reinforced with waste cornsilk fibers," Construction and Building Materials, vol. 178, pp. 204-210, 2018.

[17] K. Q. Tran, T. Satomi, and H. Takahashi, "Study on strength behavior of cement stabilized sludge reinforced with waste cornsilk fiber," International Journal of Geomate, vol. 13, no. 39, pp. 140-147, 2017.

[18] F. Chen, "Test research on mechanical property of cemented soil strengthened with basalt fiber," IOP Conference Series: Earth and Environmental Science, vol. 304, p. 052078, 2019.

[19] T. Meng, Y. Qiang, A. Hu, C. Xu, and L. Lin, "Effect of compound nano- $\mathrm{CaCO}_{3}$ addition on strength development and microstructure of cement-stabilized soil in the marine environment," Construction and Building Materials, vol. 151, pp. 775-781, 2017.

[20] B. Kalantari, A. Prasad, and B. B. K. Huat, "Cement and silica fume treated columns to improve peat ground," Arabian Journal for Science and Engineering, vol. 38, no. 4, pp. 805816, 2013.

[21] S. Kolias, V. Kasselouri-Rigopoulou, and A. Karahalios, "Stabilisation of clayey soils with high calcium fly ash and cement," Cement and Concrete Composites, vol. 27, no. 2, pp. 301-313, 2005.

[22] I. Karpisz and K. Jaworski, "Study of compressive strength evolution in soil cement samples with fly-ash admixtures," 
IOP Conference Series: Materials Science and Engineering, vol. 365, no. 3, p. 32049, 2018.

[23] N. S. Katsiotis, P. E. Tsakiridis, D. Velissariou, M. S. Katsiotis, S. M. Alhassan, and M. Beazi, "Utilization of ferronickel slag as additive in Portland cement: a hydration leaching study," Waste and Biomass Valorization, vol. 6, no. 2, pp. 177-189, 2015.

[24] Y. C. Choi and S. Choi, "Alkali-silica reactivity of cementitious materials using ferro-nickel slag fine aggregates produced in different cooling conditions," Construction and Building Materials, vol. 99, pp. 279-287, 2015.

[25] Z. Wang, W. Ni, Y. Jia, L. Zhu, and X. Huang, "Crystallization behavior of glass ceramics prepared from the mixture of nickel slag, blast furnace slag and quartz sand," Journal of Non-crystalline Solids, vol. 356, no. 31-32, pp. 1554-1558, 2010.

[26] H. Yu, T. Ma, Y. Shen, and D. Chen, "Experimental study on catalytic effect of biomass pyrolysis volatile over nickel catalyst supported by waste iron slag," International Journal of Energy Research, vol. 41, no. 14, pp. 2063-2073, 2017.

[27] W. Qiang, S. Mengxiao, Z. Yuqi, and Y. Chenghang, "Influence of ferro-nickel slag powder on the sulfate attack resistance of concrete," Journal of Tsinghua University (Science and Technology), vol. 57, no. 3, pp. 306-311, 2017.

[28] Y. Hong, X. Wu, and P. Zhang, "Construction technology and mechanical properties of a cement-soil mixing pile reinforced by basalt fibre," Advances in Materials Science and Engineering, vol. 2017, Article ID 9736465, 14 pages, 2017.

[29] M. A. M. Al-Bared and A. Marto, "A review on the geotechnical and engineering characteristics of marine clay and the modern methods of improvements," Malaysian Journal of Fundamental and Applied Sciences, vol. 13, no. 4, pp. 825-831, 2017.

[30] N. Lemonis, P. E. Tsakiridis, N. S. Katsiotis et al., "Hydration study of ternary blended cements containing ferronickel slag and natural pozzolan," Construction and Building Materials, vol. 81, no. 11, pp. 130-139, 2015.

[31] N. Yan, J. Yang, Q. Liu, and M. Dong, "Laboratory test on strength deterioration process of soil cement in seawater environment," Tumu Gongcheng Xuebao/China Civil Engineering Journal, vol. 50, no. 11, pp. 115-124, 2017.

[32] F. Xiong, H. Xing, and H. Li, "Experimental study on the effects of multiple corrosive ion coexistence on soil-cement characteristics," Soils and Foundations, vol. 59, no. 2, pp. 398-406, 2019.

[33] F. Chen and S. Tong, "Experimental study on the strength of soil-cement with additions of mineral powder and ferronickel slag powder," International Journal of Mining and Mineral Engineering, vol. 11, no. 3, pp. 218-226, 2020.

[34] C. Yu, H. Wang, A. Zhou, X. Cai, and Z. Wu, "Experimental study on strength and microstructure of cemented soil with different suctions," Journal of Materials in Civil Engineering, vol. 31, no. 6, pp. 4019081-4019082, 2019.

[35] H. Xing, X. Yang, C. Xu, and G. Ye, "Strength characteristics and mechanisms of salt-rich soil-cement," Engineering Geology, vol. 103, no. 1-2, pp. 33-38, 2009.

[36] T. Luping and N. Lars-Olof, "Chloride binding capacity and binding isotherms of OPC pastes and mortars," Cement \& Concrete Research, vol. 23, no. 2, pp. 247-253, 1993. 